慶應義塾大学学術情報リポジトリ

Keio Associated Repository of Academic resouces

\begin{tabular}{|c|l|}
\hline Title & Contribution of High Mobility Group Box-1 to the Development of Ventilator-Induced Lung Injury \\
\hline Sub Title & High Mobility Group Box-1 が人工呼吸惹起性肺損傷の発症に与える影響 \\
\hline Author & 小河, アイリーン 尚美(Ogawa, Airin Naomi) \\
\hline Publisher & 慶應医学会 \\
\hline Publication year & 2006 \\
\hline Jtitle & 慶應医学 (Journal of the Keio Medical Society). Vol.83, No.4 (2006. 12),p.5- \\
\hline JaLC DOI & \\
\hline Abstract & \\
\hline Notes & 号外 \\
\hline Genre & Journal Article \\
\hline URL & $\begin{array}{l}\text { https://koara.lib.keio.ac.jp/xoonips/modules/xoonips/detail.php?koara_id=AN00069296-2006120 } \\
\text { 2-0005 }\end{array}$ \\
\hline
\end{tabular}

慶應義塾大学学術情報リポジトリ(KOARA)に掲載されているコンテンッの著作権は、それぞれの著作者、学会または出版社/発行者に帰属し、その権利は著作権法によって 保護されています。引用にあたっては、著作権法を遵守してご利用ください。

The copyrights of content available on the KeiO Associated Repository of Academic resources (KOARA) belong to the respective authors, academic societies, or publishers/issuers, and these rights are protected by the Japanese Copyright Act. When quoting the content, please follow the Japanese copyright act. 


\section{Contribution of High Mobility Group Box-1 to the Development of Ventilator-Induced Lung Injury}

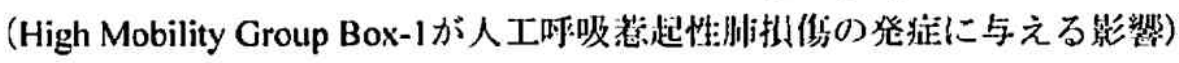

\section{小河 アイリーン尚美}

\section{内容の要旨}

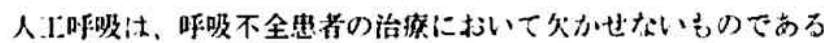
か、设证に上っては人工呼吸自体が肺推给を引き起こナ。このよう

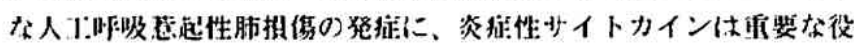
制を性たしている。 High mobility group box-I（IIMGBI）は、敗佔症

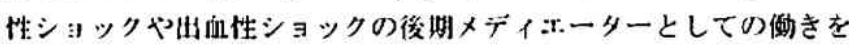

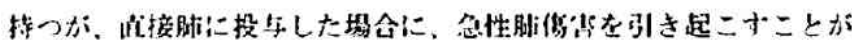

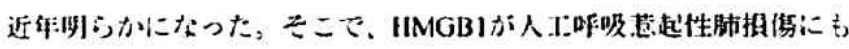

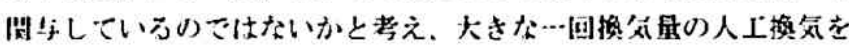
健常肺に施行した時に、HMGBIが放罒されうという仮説を㭘証し

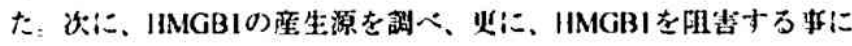

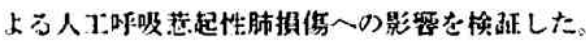

まげ、小さな一回換気量 $(8 \mathrm{ml} / \mathrm{kg})$ むしくは大きな一回換気量 $(30 \mathrm{ml} / \mathrm{kg})$ て人工喚気を 4 時開施行した无肺から、父管支肺胞洗浄

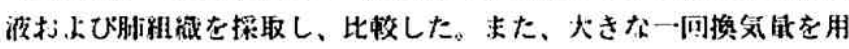

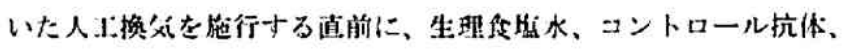

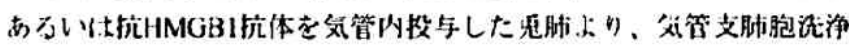

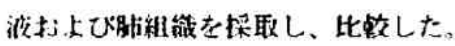

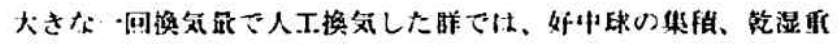

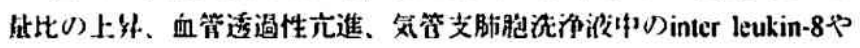

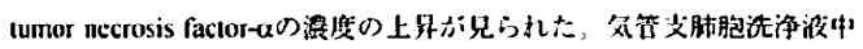

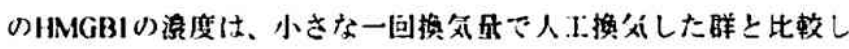
て、大きな一国換気量で人工換父した群では、5倍に增加してい

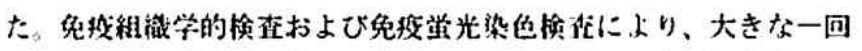

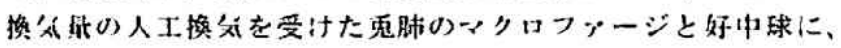

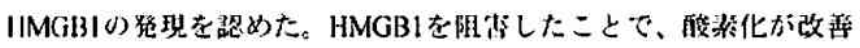

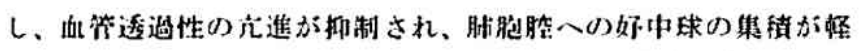

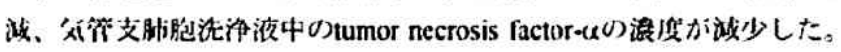

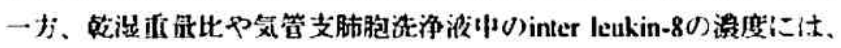
影塩かながた。

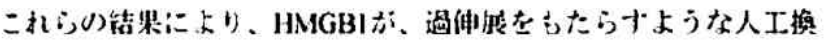

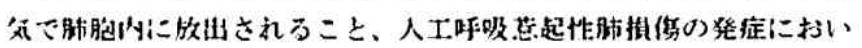
て部分的で仕あるむののそれを要化させる役款を持つことが明らか

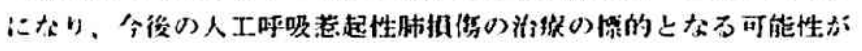
郝哟された。

\section{論文艇査の要旨}

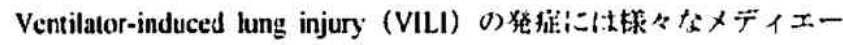
ターが咸师しているが、その全貌は明らかではない。本研究では、

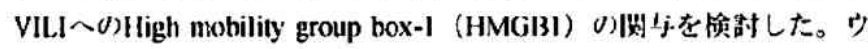
少キに $30 \mathrm{ml} / \mathrm{kg}$ という大きな一回換気拱でひ人T哳吸を施行してVILI

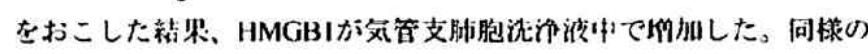

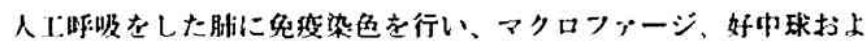
び肺胞、波細胞にHMGBIの增加を碇認した。

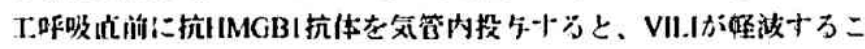
上ボ明らかとなった。

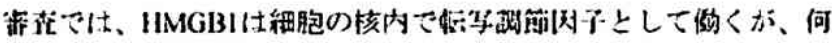

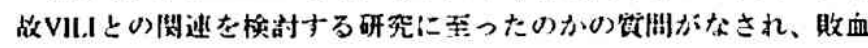

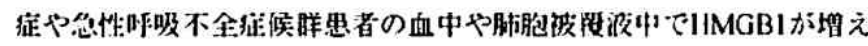

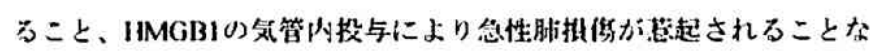

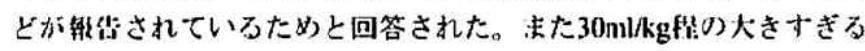

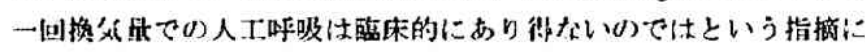

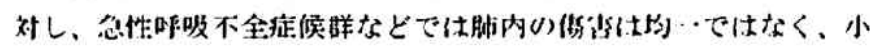

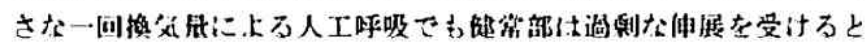

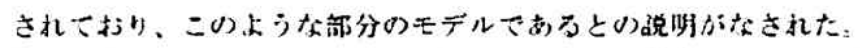

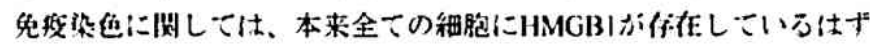

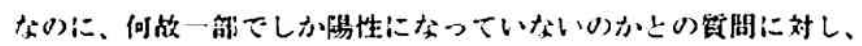

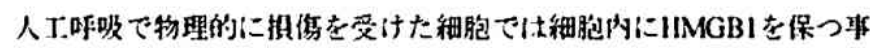
が䁖ないために染まらない辝能性があること、HMGBIは多く存在

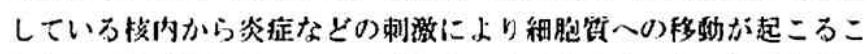
となどむげられた。VILIに閉っするサイトカインとの相互作用に

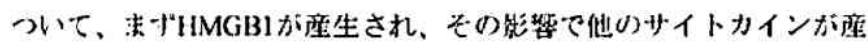

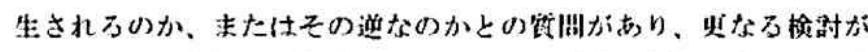

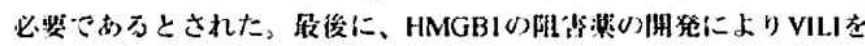

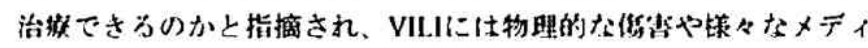

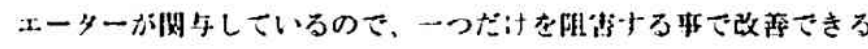

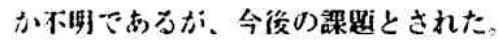

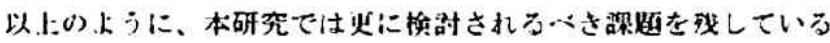
ホ、㣙ぬてHMGBIボVILIに関与していると证明した有意学な研究と 哽傮された。

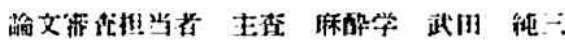

外科学 小林 紘一少 小川科学 小川

护理学 问田 保典

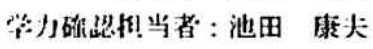

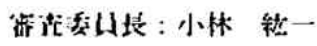

